\title{
Preliminary phytochemical screening, in vitro antioxidant activity, total polyphenolic and flavonoid content of Garcinia lanceifolia Roxb. and Citrus maxima (Burm.) Merr.
}

\author{
Partha Sarathi Bairy, Nilutpal Sharma Bora ${ }^{*}$, Bibhuti Bhusan Kakoti, Aparoop Das, Lalit Mohan Nainwal, Barnali Gogoi \\ Department of Pharmaceutical Sciences, Dibrugarh University, Dibrugarh, Assam, India.
}

\begin{tabular}{|c|c|}
\hline ARTICLE INFO & ABSTRACT \\
\hline $\begin{array}{l}\text { Article history: } \\
\text { Received on: } 23 / 02 / 2016 \\
\text { Revised on: } 14 / 03 / 2016 \\
\text { Accepted on: } 29 / 06 / 2016 \\
\text { Available online: } 26 / 09 / 2016\end{array}$ & $\begin{array}{l}\text { Garcinia lanceifolia and Citrus maxima are two indigenous fruits of East India, particularly Assam; which has } \\
\text { been used in various folkloric medicines to treat disorders ranging from diarrhea and jaundice to stomach and } \\
\text { heart problems. The main aim of this study was to establish and compare the antioxidant potential of these two } \\
\text { plants. The methanolic extracts of the bark of G. lanceifolia and C. maxima were tested for their antioxidant } \\
\text { potential using various established in vitro assay procedures. The estimation of the total phenolic and total }\end{array}$ \\
\hline $\begin{array}{l}\text { Key words: } \\
\text { Antioxidant, reactive oxygen } \\
\text { species, Garcinia lanceifolia, } \\
\text { Citrus maxima, flavonoids, } \\
\text { phenolic compounds, Assam. }\end{array}$ & $\begin{array}{l}\text { revealed that both the extracts were found to contain tannins and phenolic compounds and flavonoids along with } \\
\text { other phytoconstituents. The results reveal that both these plants have a considerable amount of antioxidant } \\
\text { activity which can be compared with each other and also the standards. }\end{array}$ \\
\hline
\end{tabular}

\section{INTRODUCTION}

Free radicals or reactive oxygen species (ROS) are generated as a result of several biological reactions or from exogenous factors and include superoxide radicals, hydroxyl radicals, singlet oxygen and hydrogen peroxides. These ROS have various physiological roles in-vivo like intercellular signaling, phagocytosis and energy production (Nandy et al., 2012). However the overproduction of these species may lead to damaged proteins, lipids and DNA, which in turn are associated with diseases like coronary artery disease, hypertension, diabetes, cancer, etc. Most of these ROS are scavenged or inactivated by various endogenous systems such as superoxide dismutase, catalase and peroxidase-glutathione system. But these systems may not be efficient enough to meet up with the demands of the

* Corresponding Author

Nilutpal Sharma Bora, Department of Pharmaceutical Sciences,

Dibrugarh University, Dibrugarh, Assam, India.

mail id:nilutpalsharma3 @ gmail.com body which leads to the dependence on exogenously available antioxidants (Sre et al., 2012). There has been resurgence in the interest in antioxidants from natural sources in recent years due to the restriction on the use of synthetic antioxidants because of their possible unwanted side effects. Hence, development of antioxidants from plant species has attracted lots of attraction and is considered desirable for prevention of many diseases (Vishwanathan et al., 2013). India is one of the 12 mega biodiversity countries and it is gifted with an enormous wealth of biodiversity. It has diverse climatic zones and wealth of vibrant ethnomedicinal traditions. There are about 45,000 plant species and 81,000 animal species recorded in India so far. Northeast Indian states are the store house of medicinal plants which are naturally grown and available in the forests. It is known for high ethnic and biological diversity and is often referred to as biological hotspot (Hajra et al, 2011). Garcinia lanceifolia Roxb, belonging to the family (Clusiaceae) is an important and endemic medicinal plant found in Assam, India. It is commonly known as "Rupahithekera" (Assamese), "Pelh" (Mizo), "Rupohi tekera" (Mising). 
The plant is a handsome, small, evergreen tree; glabrous and grows up to a height of 12 feet under the dense shade of other trees. The fruits are eaten raw or made into pickles. It has been used in folkloric medicine to treat stomach disorders, in worm infestations, diarrhea and jaundice (Bora et al., 2014). Citrus grandis (L.) Osb. or Citrus maxima (Burm.) Merr., belonging to the family Rutaceae is an indigenous plant belonging to the tropical parts of Asia. It is commonly known as "Pomelo or Shaddock" (English), Robab Tenga (Assamese), Jambura (Bengali).

The plant flowers between April to June and is reported to be used as stomachic, cardiac stimulant, antioxidant and as an appetizer. It is also reported to be used in cases of anemia (Merina et al., 2012; Mahbubur Rahman et al., 2013). Both of these plants are freely available to the people residing in the tropical South-East Asian countries.

Hence, if proven scientifically; we can use these plants as a readily available and easily accessible, low cost source of natural antioxidants. Therefore an exhaustive effort was made to determine the antioxidant and free radical scavenging activity of the bark of the plants of Garcinia lanceifolia Roxb. and Citrus maxima (Burm.) Merr.

\section{MATERIALS AND METHODS}

\section{Drugs and Chemicals}

Chemicals like 2-Deoxy- D- Ribose, Ethylene Diamine Tetra Acetic Acid Disodium Salt, Nitro blue tetrazolium chloride (NBT), NADH (reduced) disodium salt were obtained from SRL Sisco Research Laboratories Pvt. Ltd. (Mumbai, India); 1,1Diphenyl-2-picryl-hydrazyl (DPPH) from Sigma-Aldrich Chemical Co. (Steinheim, Germany). Solvents like methanol, chloroform, petroleum ether, acetone, di-ethyl ether and all other chemicals were of analytical grade (AR) and were obtained from Loba Chemie Pvt. Ltd. (Mumbai, India) and Himedia Labotratory, (Mumbai, India).

\section{Instrumentation}

All the spectrophotometric determinations were carried out using a double-beam spectrophotometer with split-beam technology, model SPECORD ${ }^{\circledR} 50$ PLUS, make Analytik Jena AG, Germany.

\section{Botanical material}

The barks of Garcinia lanceifolia and Citrus maxima were collected during the month of August, 2013 from the campus of Dibrugarh University and neighboring areas of Dibrugarh, Assam, India.

The taxonomical identification was done by Dr. A. A. Mao, Botanical Survey of India, Eastern Regional Centre, Shillong vide identification number BSI/ERC/2014/Plant identification/882. The voucher specimen of the plant was deposited in the Research Lab of the Department for further references.

\section{Preparation and selection of bark extracts}

The bark was washed thoroughly with running tap water and cut into pieces. The bark was then dried partially under sunlight and partially under the shade for a week. The dried bark pieces were then ground in mechanical grinder and stored in airtight containers free from moisture. The dried crude drug was macerated for 48 hours in petroleum ether which defatted the drug and cleared the material of any deposited debris like mold, dirt etc. The drug was packed in a soxhlet extractor and extracted successively with solvents in increasing order of their polarity. The order of the solvents was petroleum ether<chloroform<ethyl acetate $<$ methanol. The drugs were extracted using each solvent for 72 hours each or until the drug got exhausted of its phytochemical constituents. The extraction with solvents of different polarity facilitated all the constituents present in the drug to get extracted. The extracts were filtered using a muslin cloth to obtain a liquid extract which was further concentrated using a rotary evaporator at a temperature of $\left(40 \pm 5^{\circ} \mathrm{C}\right)$, model Rotavapor ${ }^{\circledR}$ R II, BUCHI, Switzerland. Preliminary phytochemical tests were carried out with all the extracts in order to evaluate for the presence of different phytochemical constituents. The most polar solvent in the whole process, i.e. only the methanolic extracts of both the plant barks had showed the presence of flavonoids and phenolic compounds. The methanolic extract of both the plants were selected for this study because crude extracts rich in phenolic compounds have been associated with the capability to retard oxidative degeneration (Kähkönen et al., 1999).

\section{Phytochemical screening of the plant extract}

A small portion of the dry extract was used for the phytochemical tests for compounds which include tannins, flavonoids, alkaloids, saponins, and steroids in accordance with the methods with little modifications (Evans, 2009; Harborne 1998).

\section{DPPH radical scavenging activity}

The radical scavenging activity of the methanolic bark extracts of Garcinia lanceifolia (MEGL) and Citrus maxima (MECM) against stable DPPH was determined spectrophotometrically using the method as described by Blois, 1958 with trivial modifications in the method (Blois, 1958). The absorption maximum of a stable DPPH radical in methanol was at $517 \mathrm{~nm}$. When DPPH reacts with an antioxidant, which can donate hydrogen, it gets reduced. $1 \mathrm{ml}$ of $0.3 \mathrm{mM}$ DPPH solution was added to $2 \mathrm{ml}$ of each different concentrations of standard solution and incubated at dark for $30 \mathrm{mins}$ at room temperature after it has been shaken vigorously. $1 \mathrm{ml}$ of $0.3 \mathrm{mM}$ DPPH solution was added to $2 \mathrm{ml}$ of methanol and this solution was taken as control and allowed to incubate at dark for 30mins at room temperature. After $30 \mathrm{~min}$, absorbance was measured at $517 \mathrm{~nm}$ taking methanol as blank using UV-Visible spectrophotometer. The percentage of inhibition was calculated by comparing the absorbance values of the control and test samples. All the tests were performed in triplicate. Ascorbic acid was used as a reference compound. The 
capability to scavenge the DPPH radical was calculated as the inhibition percentage of free radical by the sample/ standard using the following formula:

$\%$ inhibition of DPPH scavenging activity $=\frac{A 0-A t}{A 0} \times 100$

Where A0 is the absorbance of the control reaction and At is the absorbance of test/standard.

\section{Hydroxyl Radical Scavenging Activity}

Hydroxyl radical scavenging activity was measured by studying the competition between deoxyribose and MEGL/MECM for hydroxyl radical generated by $\mathrm{Fe}^{3}+$-Ascorbate-EDTA- $\mathrm{H}_{2} \mathrm{O}_{2}$ system (Fenton reaction) according to the method of Kunchandy and Rao with trivial modifications in the method (Kunchandy and Rao, 1990). Absorbance was measured spectrophotometrically at $532 \mathrm{~nm}$ against control. To $0.5 \mathrm{ml}$ of each different concentrations of Quercetin (standard), sample extracts and water (control); $0.1 \mathrm{ml}$ of 2-deoxy-2-ribose, $0.2 \mathrm{ml}$ of EDTA, $0.2 \mathrm{ml}$ of ferric chloride and $0.1 \mathrm{ml}$ of $\mathrm{H}_{2} \mathrm{O}_{2}$ were added and incubated for $1 \mathrm{hr}$ at $37^{\circ} \mathrm{C}$. After that $1 \mathrm{ml}$ of $1 \% \mathrm{TBA}$ and $1 \mathrm{ml}$ of $2.8 \%$ TCA were added to the mixture and incubated at $100{ }^{\circ} \mathrm{C}$ for $20 \mathrm{mins}$ and then cooled and absorbance was taken at $532 \mathrm{~nm}$. Reactions were carried out in triplicate spectrophotometrically taking distilled water as blank. The percentage inhibition was determined against the standard by comparing the results of the test and control compounds. The hydroxyl radical scavenging activity of the extract was reported as \% inhibition of deoxyribose degradation and was calculated as follows:

\% inhibition of Hydroxyl radical $(\mathrm{OH}-)$ scavenging activity

$$
=\frac{A 0-A t}{A 0} \times 100
$$

Where A0 is the absorbance of the control reaction and At is the absorbance in the presence of the sample of the extracts. The antioxidant activity of the extracts was expressed as $\mathrm{IC}_{50}$ from the dose inhibition curve (Bhaumik et al., 2008).

\section{Nitric Oxide Radical Scavenging Activity}

In this assay method, nitric oxide generated from sodium nitroprusside was measured by the Greiss Illosvoy reaction. Sodium nitroprusside in aqueous solution at physiological $\mathrm{pH}$ spontaneously generates nitric oxide (Marcocci et al., 1994) which interacts with oxygen to produce nitric ions that can be estimated by using Greiss reagent. Scavengers of nitric oxide compete with oxygen, which leads to reduced production of nitric oxide.

Absorbance was measured spectrophotometrically at $546 \mathrm{~nm}$ against control. To $1 \mathrm{ml}$ of each of standard solution, sample extracts and control of different concentrations separately; $1 \mathrm{ml}$ of sodium nitroprusside and $1 \mathrm{ml}$ of phosphate buffer saline $\mathrm{pH} 7.4$ were added and incubated at $25^{\circ} \mathrm{C}$ for $150 \mathrm{~min}$. After incubation, $1 \mathrm{ml}$ of the above mixture was taken and $1 \mathrm{ml}$ of Griess reagent was added to it and then allowed to stand in dark for 30 mins and then absorbance was taken at $546 \mathrm{~nm}$. The absorbance of the chromophore formed during the diazotization of nitrite with sulphanilamide and subsequent coupling with napthylethylenediamine was measured spectrophotometrically in triplicates and referred to the absorbance of standard solutions of potassium nitrite, treated in the same way with Griess reagent. Radical-scavenging activity was expressed as the inhibition percentage of free radical by the sample/ standard and was calculated using the following formula:

$$
\% \text { inhibition of nitric oxide radicals }=\frac{A 0-A t}{A 0} \times 100
$$

Where, A0 was the absorbance of the control, and At was the absorbance of test/ standard. The antioxidant activity of extracts was expressed as $\mathrm{IC}_{50}$ value. The $\mathrm{IC}_{50}$ value is defined as the concentration $(\mu \mathrm{g} / \mathrm{ml}$ of dry extract that inhibits the formation of nitric oxide by $50 \%$.

\section{Hydrogen Peroxide Radical Scavenging Activity}

The ability of the extracts to scavenge $\mathrm{H}_{2} \mathrm{O}_{2}$ was determined according to the method of Ruch et al. 1989. Absorbance was measured spectrophotometrically at $230 \mathrm{~nm}$. To $1 \mathrm{ml}$ of ascorbic acid solution and sample extracts of different concentrations, $0.6 \mathrm{ml}$ of $\mathrm{H}_{2} \mathrm{O}_{2}$ was added. Absorbance of $\mathrm{H}_{2} \mathrm{O}_{2}$ at $230 \mathrm{~nm}$ was determined after 10 min against a blank solution containing the phosphate buffer without $\mathrm{H}_{2} \mathrm{O}_{2} .1 \mathrm{ml}$ of Phosphate buffer and $0.6 \mathrm{ml}$ of $\mathrm{H}_{2} \mathrm{O}_{2}$ was used as a control. Reactions were carried out in triplicate spectrophotometrically. The percentage of $\mathrm{H}_{2} \mathrm{O}_{2}$ scavenging of both the extracts and standard compounds was calculated.

The percentage inhibition was calculated as:

$\%$ inhibition of hydrogen peroxide radicals $=\frac{A 0-A t}{A 0} \times 100$

Where AO is the absorbance of the control reaction and At is the absorbance in the presence of the extracts The antioxidant activity of the extract was expressed as $\mathrm{IC}_{50}$. The $\mathrm{IC}_{50}$ value is defined as the concentration $(\mu \mathrm{g} / \mathrm{ml})$ of dry extract that inhibits the formation of $\mathrm{H}_{2} \mathrm{O}_{2}$ radicals by $50 \%$.

\section{Determination of Reducing Power}

The reducing power of test sample was determined on the basis of the ability of their antioxidant principles to form color complexes with potassium ferricyanide, TCA and $\mathrm{FeCl}_{3}$ due to transformation of $\mathrm{Fe}^{3+}-\mathrm{Fe}^{2+}$. The reducing capacity of compound may serve as a significant indicator of its potential antioxidant activity (Barreira et al., 2008). Reducing the power of a methanolic bark extract of Garcinia lanceifolia (MEGL) and Citrus maxima (MECM) was determined according to the method of Oyaizu in 1986 with trivial modifications in the 
method (Oyaizu, 1986). From each different concentrations of ascorbic acid, samples extracts and control (water), $1 \mathrm{ml}$ was taken and added to $2.5 \mathrm{ml}$ of phosphate buffer and $2.5 \mathrm{ml}$ of potassium ferricyanide. After that it was incubated at $50^{\circ} \mathrm{C}$ for $20 \mathrm{mins}$. 20mins later $2.5 \mathrm{ml}$ of Trichloroacetic acid was added, centrifuged at $3000 \mathrm{rpm}$ for $10 \mathrm{mins}$. $2.5 \mathrm{ml}$ of supernatant layer was taken, and then mixed with $2.5 \mathrm{ml}$ of distilled water and $0.5 \mathrm{ml}$ of ferric chloride. Absorbance of the resultant mixture was measured at $700 \mathrm{~nm}$ spectrophotometrically. All the tests were performed in triplicate using distilled water as blank. Gradual enhancement of absorbance with concentration indicates the higher reducing power (Deore et al., 2009).

\section{Estimation of Total Phenolic Content}

Total soluble phenolics in the extracts were determined according to the method used by Macdonald et al., with trivial modifications using Gallic acid as a standard phenolic compound (Macdonald et al., 2008). The phenol reacts with Phosphomolybdic acid in the presence of alkaline medium to produce blue color complex known as molybdenum blue complex. $1 \mathrm{ml}$ of each concentration of Gallic acid was mixed with $5 \mathrm{ml}$ of Folin-Ciocalteu reagent (diluted 10 fold) and $4 \mathrm{ml}$ of $0.7 \mathrm{M}$ sodium carbonate. Absorbance was measured spectrophotometrically in triplicates at $765 \mathrm{~nm}$ and calibration curve was plotted. $1 \mathrm{ml}$ of each concentration of extract solution was mixed with $5 \mathrm{ml}$ of FolinCiocalteu reagent (diluted 10 fold) and $4 \mathrm{ml}$ of $0.7 \mathrm{M}$ sodium carbonate.

Absorbance was measured spectrophotometrically in triplicates at $765 \mathrm{~nm} .1 \mathrm{ml}$ of distilled water was mixed with $5 \mathrm{ml}$ of Folin-Ciocalteu reagent and $4 \mathrm{ml}$ of sodium carbonate. This was taken as a control and absorbance was measured spectrophotometrically at $765 \mathrm{~nm}$. The total phenolic content in the extract expressed in Gallic acid equivalents (GAE) was calculated by the following formula:

$$
T=C \times \frac{V}{M}
$$

where, $\mathrm{T}=$ Total phenolic contents, $\mathrm{mg} \mathrm{g}^{-1}$ plant extract, in Gallic Acid

Equivalent (GAE),

$\mathrm{C}=$ Concentration $\left(\mathrm{mg} \mathrm{ml} \mathrm{m}^{-1}\right)$ of Gallic acid obtained from the calibration curve,

$\mathrm{V}=$ Volume of extract $(\mathrm{ml})$,

$\mathrm{M}=$ Weight (mg) of methanolic plant extract.

\section{Estimation of Total Flavonoid Content}

Total soluble flavonoid content of the extracts was determined with aluminium chloride using quercetin as the standard according to the method of Ebrahimzaded et al., with trivial modifications in the method (of Ebrahimzaded et al., 2001). To $1 \mathrm{ml}$ of each different concentration of quercetin, $2 \mathrm{ml}$ of methanol was added to each concentration. Then it was mixed with $0.2 \mathrm{ml}$ of aluminium chloride and $0.2 \mathrm{ml}$ of potassium acetate and finally $5.6 \mathrm{ml}$ of distilled water was added to each concentration. To $1 \mathrm{ml}$ of of extract, $2 \mathrm{ml}$ of methanol was added.
Then it was mixed with $0.2 \mathrm{ml}$ of aluminium chloride and $0.2 \mathrm{ml}$ of potassium acetate and finally $5.6 \mathrm{ml}$ of distilled water was added to each concentration. All the samples were incubated for $30 \mathrm{mins}$ at room temperature and absorbance was measured at $415 \mathrm{~nm}$ against control. The total flavonoid content in the fractions was determined as $\mu \mathrm{g}$ Quercetin equivalent by using the standard quercetin graph and using the following formula;

$$
T=C \times \frac{V}{M}
$$

where, $\mathrm{T}=$ Total flavonoid content, $\mathrm{mg}^{-1}$ plant extract, in Quercetin Equivalent (QE),

$\mathrm{C}=$ Concentration $\left.(\mathrm{mg} \mathrm{ml})^{-1}\right)$ of Quercetin obtained from the calibration curve,

$\mathrm{V}=$ Volume of extract $(\mathrm{ml})$,

$\mathrm{M}=$ Weight (mg) of methanolic plant extract.

\section{Statistical analysis}

All data on measurement of antioxidant activities are the average of duplicate analyses. The raw analyses were performed in triplicate. The data were recorded as mean \pm standard error of mean and analyzed by GraphPad PRISM (Version 5.03 for Windows December 10, 2009). One way analysis of variance was performed. Significant differences between means were determined by Dunnett's multiple comparison tests. Values of $\mathrm{p}<$ 0.05 were regarded as significant and $p<0.01$ very significant.

\section{RESULTS AND DISCUSSIONS}

\section{Phytochemical screening of the plant extracts}

The qualitative phytochemical estimation of both the extracts was done and the results have been tabulated in Table 1. Both the extracts showed the presence of a number of important phytoconstituents out of which the tannins, phenolics and flavonoids were common in both and of the utmost importance. The MEGL also showed the presence of amino acids, carbohydrates, glycosides, lignins, proteins and triterpenoids. While the MECM showed the presence of the carbohydrates, flavonoids, glycosides and triterpenoids.

Table 1: Phytochemical screening of G. lanceifolia and C. maxima methanolic bark extracts.

\begin{tabular}{ccc} 
Plant Constituents & $\begin{array}{c}\text { Methanolic extract } \\
\text { of the bark of } \boldsymbol{G} . \\
\text { lanceifolia }\end{array}$ & $\begin{array}{c}\text { Methanolic extract } \\
\text { of the bark of } \boldsymbol{C} . \\
\text { maxima }\end{array}$ \\
\hline Alkaloids & - & - \\
Amino acids & + & - \\
Carbohydrates & + & + \\
Fats and Oils & - & - \\
Flavonoids & + & + \\
Glycosides & + & + \\
Gums & - & - \\
Lignins & + & - \\
Proteins & + & - \\
Steroids & - & + \\
Triterpenoids & + & - \\
Saponins & - & \\
Tannins and Phenolic & + & \\
Compounds & &
\end{tabular}




\section{DPPH radical scavenging activity}

The scavenging ability of MEGL and MECM was compared with the standard ascorbic acid and is shown in Figure 1. The DPPH Scavenging activity of the two extracts and the standard was expressed as percentage inhibition. The MEGL showed a better scavenging effect on DPPH radicals than MECM. However, it was not as effective as the standard ascorbic acid. The scavenging activity of both the extracts was found to increase in a dose dependent manner. The MEGL showed antioxidant activity with $\mathrm{IC}_{50}$ value of $29.21 \mu \mathrm{g} / \mathrm{ml}$ while $\mathrm{MECM}$ exhibited an $\mathrm{IC}_{50}$ value of $33.05 \mu \mathrm{g} / \mathrm{ml}$. However the known antioxidant ascorbic acid exhibited an $\mathrm{IC}_{50}$ value of $17.37 \mu \mathrm{g} / \mathrm{ml}$. At the concentration of $80 \mu \mathrm{g} / \mathrm{mL}$, MEGL showed $81.33 \%$ inhibition while that of ascorbic acid was $87.41 \%$. At other concentrations, percentage inhibition of MEGL was found to be marginally less than that of ascorbic acid.

\section{DPPH radical scavenging activity}

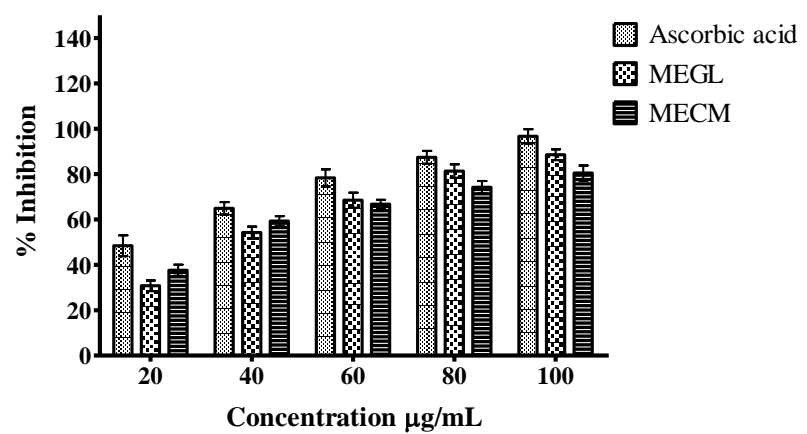

Fig. 1: Comparison of the DPPH radical scavenging activity of ascorbic acid (standard), methanolic extract of Garcinia lanceifolia bark (MEGL) and Citrus maxima bark (MECM), all values is expressed as Mean \pm S.E.M.

\section{Hydroxyl Radical (Oh -) Scavenging Activity}

The scavenging ability of MEGL and MECM on OHradical is shown in Figure 2 and compared with ascorbic acid. The hydroxyl radical scavenging activity is apparent from the gradual increase in percentage scavenging activity with increasing concentration of methanolic bark extract of Garcinia lanceifolia and reference standard ascorbic acid. The $\mathrm{IC}_{50}$ values were found to be $291.85 \mu \mathrm{g} / \mathrm{ml}$ for MEGL, $278.50 \mu \mathrm{g} / \mathrm{ml}$ for MECM and $178.40 \mu \mathrm{g} / \mathrm{ml}$ for ascorbic acid respectively.

\section{Hydroxyl radical scavenging activity}

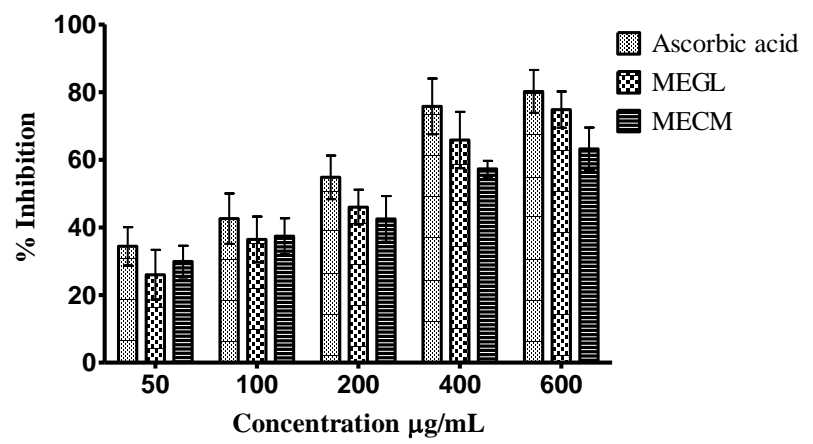

Fig. 2: Comparison of the hydroxyl radical scavenging activity of ascorbic acid (standard), methanolic extract of Garcinia lanceifolia bark (MEGL) and Citrus maxima bark (MECM), all values are expressed as Mean \pm S.E.M.

\section{Nitric Oxide Radical Scavenging Activity}

Nitric oxide radical generated from sodium nitroprusside at physiological $\mathrm{pH}$ was found to be inhibited by MEGL and MECM. Garcinia lanceifolia and Citrus maxima at varying concentrations showed a remarkable inhibitory effect of nitric oxide radical- scavenging activity (Figure 3). Results showed the percentage of inhibition in a dose dependent manner. The concentration of Garcinia lanceifolia needed for $50 \%$ inhibition $\left(\mathrm{IC}_{50}\right)$ was found to be $210.50 \mu \mathrm{g} / \mathrm{ml}$, for Citrus maxima it was $338.2 \mu \mathrm{g} / \mathrm{ml}$ whereas $89.03 \mu \mathrm{g} / \mathrm{ml}$ was needed for curcumin respectively.

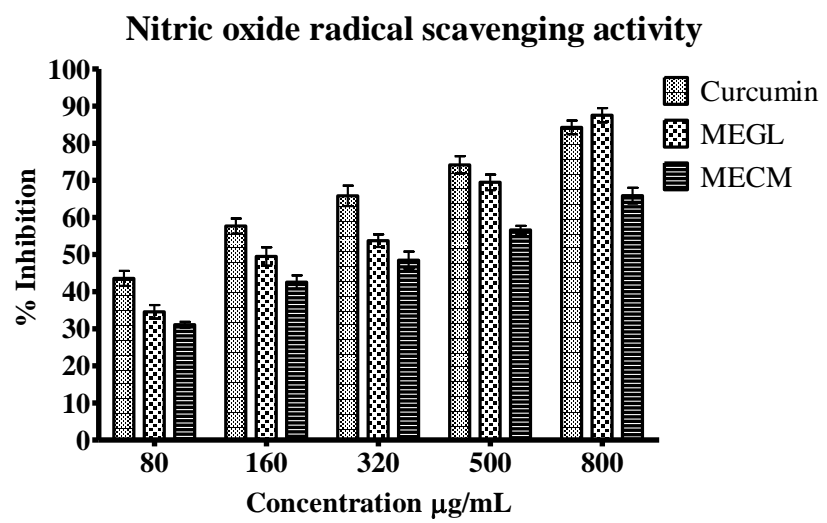

Fig. 3: Comparison of the nitric oxide radical scavenging activity of curcumin (standard), methanolic extract of Garcinia lanceifolia bark (MEGL) and Citrus Maxima bark (MECM), all values are expressed as Mean \pm S.E.M.

\section{Hydrogen Peroxide Radical Scavenging Activity}

Hydrogen peroxide scavenging activity of the extract is compared with ascorbic acid. The results are shown in Figure 4. The results showed that MEGL and MECM were effective in scavenging hydrogen peroxide in a dose dependant manner. The result is comparable with that of reference standard ascorbic acid. The $\mathrm{IC}_{50}$ value of ascorbic acid, MEGL and MECM are 117.13 $\mu \mathrm{g} / \mathrm{ml}, 77.19 \mu \mathrm{g} / \mathrm{ml}$ and $600 \mu \mathrm{g} / \mathrm{ml}$ respectively. The results showed that MEGL was more effective in scavenging hydrogen peroxide than the standard. The result is comparable with that of reference standard ascorbic acid.

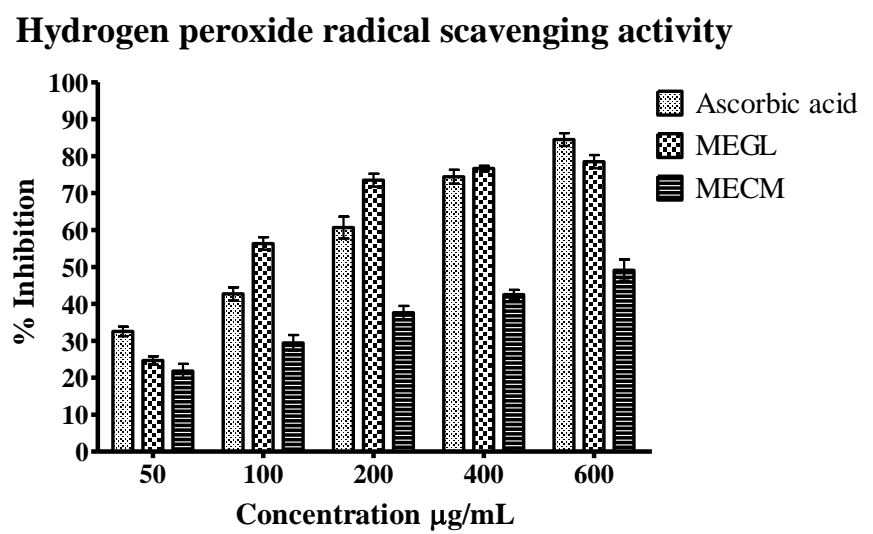

Fig. 4: Comparison of the hydrogen peroxide radical scavenging activity of ascorbic acid (standard), methanolic extract of Garcinia lanceifolia bark (MEGL) and Citrus maxima bark (MECM), all values are expressed as Mean \pm S.E.M. 


\section{Reducing power assay}

The measurement of reducing capacity was for $\mathrm{Fe}^{3+}-\mathrm{Fe}^{2+}$ transformation in the presence of the extract was estimated. The reducing capacity of a compound may serve as a significant indicator of its potential antioxidant activity. The results of reducing power of MEGL and MECM are shown in Figure 5. The result shows the extent of the reduction in terms of absorption value at $700 \mathrm{~nm}$. There is a direct association between antioxidant activity and reduction capacity. The reducing power was determined in comparison with standard drug Ascorbic acid and the extent of reduction exhibited in following order: ascorbic acid > MECM > MEGL. Reducing power will increase accordingly with the increase in absorbance.

\section{Reducing power assay}

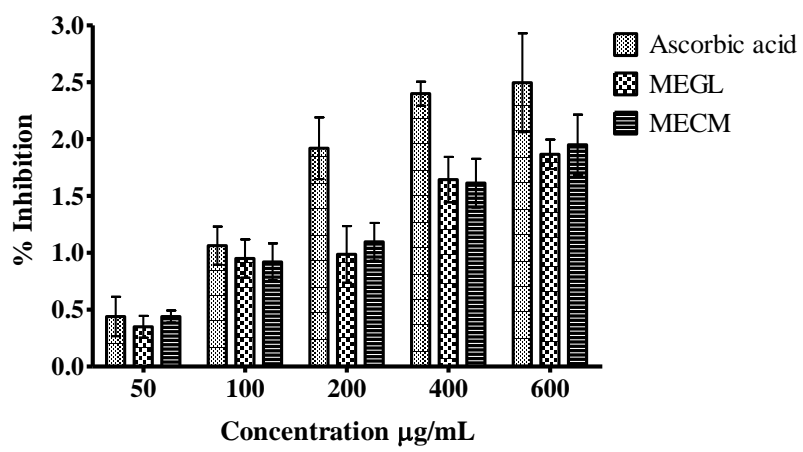

Fig. 5: Comparison of reducing power of ascorbic acid (standard), methanolic extract of Garcinia lanceifolia bark (MEGL) and Citrus maxima bark (MECM), all values are expressed as Mean \pm S.E.M.

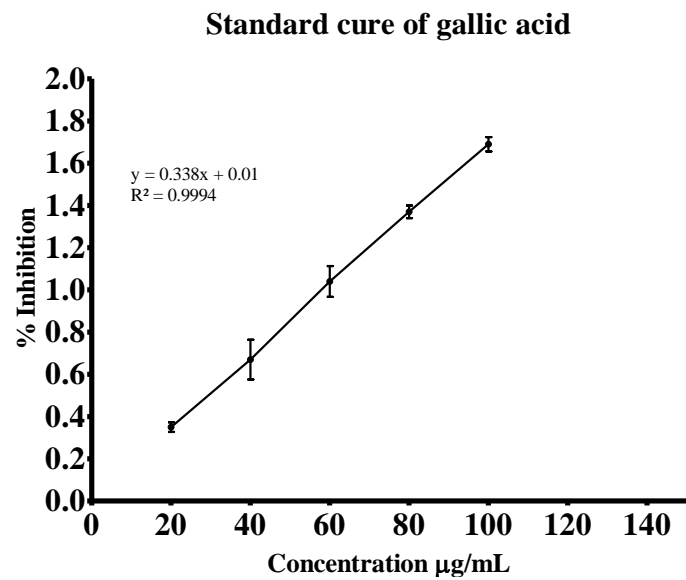

Fig. 6: Calibration curve of Gallic acid (standard), all values are expressed as Mean \pm S.E.M

\section{Estimation of Total Phenolic Content}

The content of phenolic compound in the methanolic bark extract of Garcinia lanceifolia and Citrus maxima measured by Folin-Ciocalteu reagent in terms of Gallic acid equivalent (GAE) was $6.70 \mathrm{mg} \mathrm{g}^{-1}$ and $\mathbf{5 . 2 0} \mathrm{mg} \mathrm{g}^{-1}$ respectively. The amount of polyphenolic compounds present was derived from the absorbance of the sample solutions prepared and the standard which has been tabulated in Table 2. Figure 6 shows the calibration curve of Gallic acid. These results suggest that higher levels of antioxidant activity were due to the presence of phenolic components.

Table 2: Observation of calibration curve in total phenolic estimation.

\begin{tabular}{cc}
\hline Concentration $\left(\mathbf{m g ~ m l}^{\mathbf{- 1}}\right)$ & Absorbance $($ Mean \pm S.E.M $)$ \\
\hline 20 & $0.35 \pm 0.023$ \\
40 & $0.67 \pm 0.094$ \\
60 & $1.04 \pm 0.073$ \\
80 & $1.37 \pm 0.030$ \\
100 & $1.69 \pm 1.034$ \\
MEGL & $\mathbf{0 . 2 1} \pm \mathbf{0 . 0 2 2}$ \\
MECM & $\mathbf{0 . 1 5} \pm \mathbf{0 . 0 4 1}$ \\
\hline
\end{tabular}

\section{Estimation of total flavonoids}

The content of flavonoid compound in the methanolic bark extract of Garcinia lanceifolia measured by aluminium chloride method in terms of Quercetin equivalent (QE) was found to be $\mathbf{6 1 . 1 7} \mathrm{mg} \mathrm{g}^{-1}$ and $\mathbf{4 8 . 5 4} \mathrm{mg} \mathrm{g}^{-1}$ respectively. The absorbance of the standard and the samples is tabulated in Table 3. Quercetin was used as the standard and the amount of the total flavonoids present were derived from it which is shown in Figure 7. It has been recognized that flavonoids exert considerable antioxidant activity and exhibit substantial beneficial effects on human nutrition and health.

Table 3: Observation of calibration curve in Total Flavonoid Estimation.

\begin{tabular}{cc}
\hline Concentration $\left(\mathbf{m g ~ m l}^{-1}\right)$ & Absorbance $($ Mean \pm S.E.M $)$ \\
\hline 50 & $0.45 \pm 0.01$ \\
100 & $0.85 \pm 0.09$ \\
150 & $1.27 \pm 0.26$ \\
200 & $1.67 \pm 0.08$ \\
250 & $2.10 \pm 0.34$ \\
MEGL & $\mathbf{0 . 5 2} \pm \mathbf{0 . 0 8}$ \\
MECM & $\mathbf{0 . 3 3} \pm \mathbf{0 . 0 3 0}$ \\
\hline
\end{tabular}

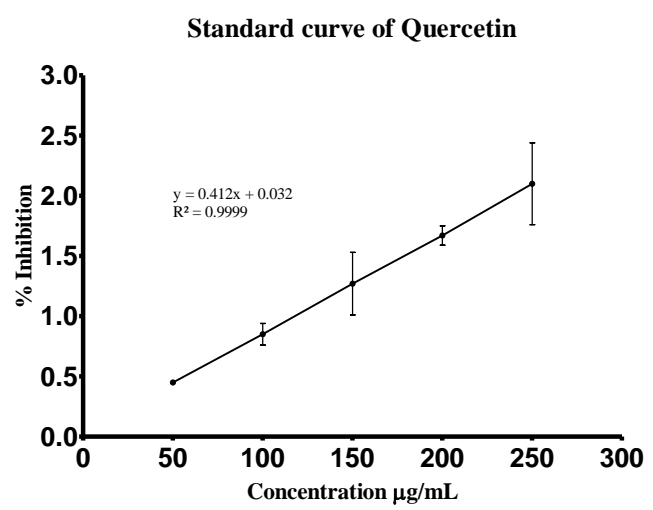

Fig. 6: Calibration curve of quercetin (standard), all values are expressed as Mean \pm S.E.M

\section{CONCLUSION}

In conclusion from this study, it has been found that the methanolic extract of the bark of Citrus maxima and Garcinia lanceifolia, has a considerable amount of antioxidant activity which are comparable to the standard in some assay, while in some they are found to be more potent than that of the standard. This study provides us with a detailed overview of the antioxidant potential of two important, endemic and consumable plants of 
Assam. These plants are consumed by the local people and since they are a source of very potent antioxidants they are providing us with answers to our various diseases and disorders. They are also a potential alternative to chemical antioxidants as they will be naturally available, cheaper and with fewer side effects.

\section{ABBREVIATIONS}

MEGL: Methanolic extract of the bark of Garcinia lanceifolia.

MECM: Methanolic extract of the bark of Citrus maxima.

\section{CONFLICT OF INTEREST}

The authors declare that there is no conflict of interests regarding the publication of this paper.

\section{ACKNOWLEDGEMENTS}

The authors are thankful to Department of Pharmaceutical Sciences, Dibrugarh University, India for providing the research facilities for this work.

Financial support and sponsorship: Authors are thankful to AICTE (All India Council of Technical Education), Research Promotion Scheme (RPS) 2011 for providing grant (Grant No: 8023/RIB/RPS-10/ (NER) /2011-12).

Conflict of interest: There are no conflicts of interest.

\section{REFERENCES}

Barreira JC, Ferreira IC, Oliveira MB, Pereira JA. Antioxidant activity and bioactive compounds of ten Portuguese regional and commercial almond cultivars. Food and Chemical Toxicology. 2008 46(6):2230-5

Bhaumik UK, Kumar AD, Selvan VT, Saha P, Gupta M, Mazumder UK. Antioxidant and free radical scavenging property of methanol extract of Blumea lanceolaria leaf in different in vitro models. Pharmacologyonline. 2008;2:74-89.

Blois MS. Antioxidant determinations by the use of a stable free radical. Nature, 1958; 181: 1199-1200.

Bora NS, Kakoti BB, Gogoi BA. Investigation of in vitro anthelmintic activity of Garcinia lanceifolia bark in Pheretima posthuma (Indian adult earthworm). PHARMANEST. 2014;5(3):2007-10.

Ebrahimzadeh MA, Pourmorad F, Bekhradnia AR. Iron chelating activity, phenol and flavonoid content of some medicinal plants from Iran. African Journal of Biotechnology. 2008;7(18).

Evans WC. 2009. Trease and Evans Pharmacognosy. London: Saunders Limited.

Halliwell B, Gutteridge JM. Free radicals in biology and medicine. Oxford University Press, USA; 2015 Jul 1.

Harborne JB. 1998. Phytochemical methods: A guide to modern techniques of plant analysis. London: Chapman \& Hall.
Kähkönen MP, Hopia AI, Vuorela HJ, Rauha JP, Pihlaja K, Kujala TS, Heinonen M. Antioxidant activity of plant extracts containing phenolic compounds. Journal of agricultural and food chemistry. 1999; 47(10):3954-62

Kunchandy E, Rao MNA. Oxygen radical scavenging activity of curcumin. International Journal of Pharmacognosy, 1990; 58(3): 237 240 .

Marcocci L, Maguire JJ, Droylefaix MT, Packer L. The nitric oxide-scavenging properties of Ginkgo biloba extract EGb 761 Biochemical and biophysical research communications. 1994; 201(2): 748-55.

McDonald S, Prenzler PD, Antolovich M, Robards K. Phenolic content and antioxidant activity of olive extracts. Food chemistry. 2001 Apr 30;73(1):73-84

Merina N, Chandra KJ, Jibon K. Medicinal plants with potential anticancer activities: A Review. Int Res J Pharm. 2012;3(6):26-30.

Muruhan S, Selvaraj S, Viswanathan PK. In vitro antioxidant activities of Solanum surattense leaf extract. Asian Pacific journal of tropical biomedicine. 2013;3(1):28-34.

Nandy S, Paul HS, Barman NR, Chakraborty B. In vitro evaluation of antioxidant activity of Leucas plukenetii (Roth) Spreng. Asian J Plant Sci Res. 2012; 2: 254-62.

Nath M, Dutta BK, Hajra PK. Medicinal plants used in major diseases by Dimasa tribe of Barak Valley. Assam University Journal of Science and Technology. 2011; 7(1):18-26.

Oyaizu M. Studies on products of browning reaction-antioxidative activities of products of browning reaction prepared from glucosamine. Eiyogaku zasshi= Japanese journal of nutrition. 1986.

Rahman AH, Biswas MC, Islam AK, Zaman AT. Assessment of Traditional Medicinal Plants Used by Local People of Monirampur Thana under Jessore District of Bangladesh. Wudpecker Journal of Medicinal Plants. 2013; 2(6): 099-109.

Ruch RJ, Cheng SJ, Klaunig JE. Prevention of cytotoxicity and inhibition of intercellular communication by antioxidant catechins isolated from Chinese green tea. Carcinogenesis. 1989; 10(6): 1003-8.

SL D, Khadabadi SS, Baviskar BA, Khangenbam RA, Koli US, Daga NP, Gadbail PA, Jain PA. In vitro antioxidant activity and phenolic content of Croton caudatum. In vitro. 2009; 1(2): 174-6.

Sre PR, Sheila T, Murugesan K. Phytochemical screening and "in-vitro" anti-oxidant activity of methanolic root extract of Erythrina indica. Asian Pacific Journal of Tropical Biomedicine. 2012; 2(3): S1696700 .

\section{How to cite this article:}

Bairy PS, Bora NS, Kakoti BB, Das A, Nainwal LM, Gogoi B. Preliminary phytochemical screening, in vitro antioxidant activity, total polyphenolic and flavonoid content of Garcinia lanceifolia Roxb. and Citrus maxima (Burm.) Merr. J App Pharm Sci, 2016; 6 (09): 133-139. 